\title{
Utilization of E-Learning-Based ICT Learning Using the Google Classroom Application During the COVID-19 Pandemic
}

\section{Muttaqin Kholis Ali1 ${ }^{*}$, Hasan Maksum²}

1,2 Universitas Negeri Padang, Padang, Indonesia

A R T I C L E I N F O

Article history:

Received 18 August

2020

Received in revised

Form 06 September

2020

Accepted 18 October

2020

Available online 01

November 2020

Keywords:

E-Learning, Google

Classroom, Covid-19.

\begin{abstract}
A B S T R A C T
The impact of the Covid-19 pandemic has brought changes to the learning process, from face-to-face at school to online distance learning called e-learning. The research objective is to describe the implementation of elearning-based ICT learning using the Google Classroom application during the Covid-19 pandemic in public high schools. The research used a qualitative approach and was conducted on class X MIA students. 1. Data collection was carried out by observation, interviews, and documentation study. Data analysis was carried out, namely data reduction, data presentation, and concluding. The results showed that the use of the google classroom application made the ICT learning process easier during the covid-19 period. The advantages of the google classroom application as a learning medium are: (1) it has flexibility in terms of time and place; (2) the application is easy to understand and operate; (3) The use of applications is effective and efficient; (4) the learning evaluation process is more accurate. This research concludes that the google classroom application facilitates the ICT learning process during the covid-19 period.
\end{abstract}

\section{Introduction}

Originating from the city of Wuhan in China, COVID-19 is a highly contagious disease or disease caused by the severe acute respiratory syndrome coronavirus 2 (SARS-CoV-2), which has affected all continents and become a pandemic, (Remuzzi \& Remuzzi, 2020; Baiyere et al., 2016). This virus can spread very quickly between individuals through close contact and has caused millions of deaths. Since then, due to its severity and severity as well as the largest global health crisis in human civilization for centuries, COVID-19 has been called a pandemic.

The Covid-19 outbreak that is currently hitting has had a huge impact on countries around the world, including Indonesia. The impact of Covid-19 has brought very significant changes, one of which is the changes that have occurred in the world of education. Education is one of the defining factors in building a good nation (Baiyere et al., 2016). So, for the smoothness of the teaching and learning process, innovation is needed to adapt to new normal conditions

Amid the various difficulties faced during the pandemic, teachers are required to get used to utilizing the e-learning platform to impart education to students. E-learning was first used at the CBT system seminar in 1999. It refers to a learning system that is conducted through electronic media, also described as online or virtual learning. E-learning offers a convenient way to share reading material via the internet connection through documents, email, presentations, or webinars. IT has become a prominent part of modern education these days, showing the large involvement of ICT in the present teachinglearning process (Anderson, 2005; Sadikin \& Hamidah, 2020). Educators or teachers can share study and lecture materials in the form of a PPT, PDF, or Word documents by uploading it to several tools, such as their respective school or university webpage, email, or another supported platform like WhatsApp or Google Classroom to maximum students during the lockdown.

Due to the main spread of Covid-19 is through close contact, and the virus can survive in the air for a certain period of time, the government recommends society to stay at home and apply physical and social distancing to reduce the rate of spread of the coronavirus. The government made a policy, namely learning from home so that learning is carried out online by utilizing the development of information technology as a learning medium, which is called e-learning (Roni Hamdani \& Priatna, 2020; Sadikin \& Hamidah, 2020). 
E-learning is defined as technology-based learning with learning materials sent electronically to students via computer/internet networks so that students can acquire knowledge without having to face the teacher in class (Alqudah et al., 2020; Mayer, 2019) E-Learning is an umbrella term for all technologyenabled learning using a variety of teaching and learning tools, such as telephone, audio, videotape, satellite or computer transmission. Thus, using e-learning makes it easier for educators and students to conduct distance learning.

Electronic learning or E-learning is a learning method that is carried out by utilizing the function of the internet in activities learning by making electronic facilities as a medium learning. Several definitions of e-learning can be put forward, including the definition of e-learning by Jaya Kumar C. Koran (2002): it is a learning that uses electronic circuits (WAN, LAN, or the internet) to convey learning content, guidance, or interaction. Meanwhile, Dong (in Kamarga, 2002) defines e-learning as a learning activity asynchronously via computer electronic devices that obtain learning materials according to their needs. From this definition, it can be understood that in addition to utilizing internet facilities, e-learning uses hardware such as computers or laptops, and networks that can connect students and teachers as well. The relationship that is built is an educational relationship or interaction between students and teachers. Also, from this definition, it can be understood that the meaning of learning with e-learning requires its own supporting infrastructure, especially an internet connection.

E-learning cannot be separated from the use of the internet. Romi Satria Wahono stated that elearning infrastructure can be in the form of internet, computer networks, personal computers (PCs), and multimedia equipment. In addition to the aforementioned facilities, teleconference equipment is also needed if you want to conduct distance learning face-to-face via teleconference.

Learning through e-learning can be applied to various subjects, one of which is ICT. ICT is defined as the study of the design, development, implementation, and management of computer-based information systems, especially software and hardware applications. Information technology according to this definition is related to the use of computers electronically and computer software to change, store, protect, process, transmit, and retrieve all information safely (Hamid, 2016; Kristinawati et al., 2018; Yaumi, 2012). ICT makes a positive contribution to learning in schools and to be effective it requires conscious efforts to mutually cooperate between principals, teachers, parents, students, and all supporting components including adequate infrastructure. ICT in education is as a learning resource, learning aids, learning facilities, competency standards, administrative systems (Hamid, 2016). Learning ICT by elearning can be optimal if it is supported by learning media.

In accordance with Ministerial Regulation (Permen) number 22 of 2006 regarding content standards for Primary and Secondary Education units that support the KTSP (Education Unit Level Curriculum) program that is enforced in schools, Information and Communication Technology (ICT) subjects are mandatory subjects that must be given to students in junior high school. Competency Standards for Graduates (SKL) of ICT subjects in KTSP at the junior high school level are students are expected to be able to understand the use of ICT and its prospects in the future, master the basics of computer skills, understand the basic principles of the internet and intranet to get information, and use word and number processing tools to produce simple documents.

One of the materials provided in ICT lessons is the internet. The rapid development of the internet forced us to be more creative in its use. We have experienced the positive and negative impacts of the development of the internet. One of the positive impacts that we experienced from it is the many facilities to create a website or web blog for free on the internet that can broadcast ourselves to the world. The use of ICT (Information and Communication Technology) is an effective and efficient way to convey information and communicate with each other. The technology that supports this method is getting refined from time to time.

One way that can be used to carry out the learning process online is by using the platform provided by Google, Google Classroom. The use of Google Classroom can be multiplatform, namely through computers and devices. Through the Google Classroom application, it is assumed that learning objectives will be easier for teachers or educators to manage to learn and convey information accurately to students (Hakim, 2016). Through blended learning, it is convenient for students to be active in constructing their knowledge. Teachers can also take advantage of various features found in the Google Classroom application such as assignments, grading, communication, time-cost, archive courses, mobile applications, and privacy.

The implementation of learning with Google Classroom makes it easier to evaluate the implementation of the teaching and learning process both in class and outside the classroom. Learning can be combined between conventional methods and e-learning or called Blended Learning. Created by Google, it aims to help lecturers and students to organize classes, as well as communicate with students 
without having to be tied to class schedules. Besides that, the lecturer can assign assignments and directly give grades to students.

E-learning is a learning process that uses internet technology to improve the environment study with a wide range of rich content. E-learning uses learning media via the internet to send a series of solutions that can increase knowledge and skills. Each learning method must contain organizing formula learning materials, delivery strategies, and management activities by paying attention to the factors of learning objectives, learning barriers, characteristics of students, in order to be able to obtain effectiveness, efficiency, and attractiveness of learning (Miarso, 2004).

One of the learning media used in e-learning is the Google Classroom application. Google Classroom is an application that allows the creation of classrooms in cyberspace. The Google Classroom application can be used by educators and students in the implementation of distance learning and serves to facilitate the teaching and learning process from a distance (Dewi et al., 2020; Setiawan \& Wicaksono, 2020). Educators must understand the use of the application, then make students understand how to use the application (Shaharanee, Jamil, \& Rodzi, 2016). Through this application, educators and students can distribute and collect assignments.

Google Classroom was used as a facilitator of the interaction of a teacher or a professor with students in the virtual world (Liu \& Chuang, 2016). Google Classroom is considered to be one of the best platforms for improving teacher workflow. This application provides all the modern features that make Google Classroom an ideal platform of learning to improve communication used with learners. To use Google Classroom via computer and telephone, it only needs to download via the Play Store or App Store. This application makes it easy for educators and students to carry out the learning process deeper because the Google Classroom application, both educators and students, can distribute assignments, collect assignments, and assess assignments at home or anywhere without being bound by time limits or class hours. The most influential advantage lies in its accessibility, flexibility in scheduling students, and the ability to adapt to work (Al-Maroof \& Al-Emran, 2018)

Working together with teachers across the country, the utilization of E-Learning-based ICT learning using the Google Classroom application during the COVID-19 pandemic makes learning more collaborative, productive, and meaningful. They create the Classroom as a tool that is efficient and easy to use, so help teachers manage assignments. With Classroom, teachers can create classes, distribute assignments, give grades, send feedback, and notice everything in one place with ease.

Google Classroom is an action management system for learning and teaching which can also be used to house archives. Students and teachers can conveniently execute e-learning schemes or remote learning and teaching activities via this platform that can be accessed from mobile or desktop devices. The first step that needs to be done to begin using this program is to download it for free, either from the Play Store or the App Store. This application can be installed for use via the desktop through the website classroom.google.com.

In addition, using a Gmail account, users can log in to the system. The user, operating as the educator, will then be given the option for creating a class. The options are versatile and can be modified to fit your needs. After the class is created, the teacher may invite students to enter the class by giving them a unique number or code combination of numbers and letters. The purpose of uploading a number of main files is one of the main features of Google Classroom. Because, on the main page, Google Classroom provides educators with a place to define the class profile. Teachers may also insert syllabus, class rules, or even other instructions in this section.

Apart from that, Google Classroom also provides an Announcement feature. Through this feature, teachers can easily share important announcements for all students. Now, when it comes to assignments, Google Classroom also makes it easy for teachers to give assignments through the Assignments feature. The teacher can also complete the assignment with a detailed description, deadline, also insert a number of instructions, pictures, and videos. For classrooms, Google Classroom provides few options that can be selected according to your needs: 1) The first option is stream or forum. Through this classroom option, teachers and students can interact directly to have discussions. 2) The next option is Classwork. Through this class, teachers and students are given the convenience of distributing existing assignments. 3) Furthermore, Google Classroom also presents a Grades section which is used to recapitulate student assessments. Through all the features in Google Classroom, teachers and students can continue to carry out teaching and learning activities even without meeting face to face. Remember, through Google Classroom, students and teachers can easily convey information, assign assignments, and have open discussions.

Google provided the Google Classroom application as an internet-based service that supported the e-learning system (Martínez-Monés et al., 2017). The platform was designed to assist teachers to 
create tasks and hand them out easily to the students in a smart paperless way. Also, to use the Classroom, users must have an account on Google. Only schools that have Google Apps for Education can use it.

Lecturers or teachers can freely distribute a scientific assessment as well as provide an independent assignment to the students (Wijaya, 2016). Also, professors can create online discussions in an open space for their students. Google Classroom utilization can be made through multiple platforms, i.e., through mobile phones and computers. Students and lecturers can visit https://classroom.google.com or simply download it for free via the iOS app store or Android Play Store with the keywords "Google classroom".

Released on August 12, 2014, Google Classroom education is one of the features provided by Google Apps for Education (GAFE). The application allows the creation of classrooms in cyberspace. Google Classroom can be used as a means for the hand out of tasks, assignments submission, also assessment. It can be downloaded for free or without any charge by registering on the Google account application for education. Google Classroom app is beneficial and multipurpose for online learning and teaching. It can be obtained free of charge and can be used on any device. One of the sophistications of this platform is that it can be used collaboratively with other groups. There are so many advantages of using Google Classroom as one of the Learning Management Systems (LSM) (Izenstark \& Leahy, 2015).

The google classroom application is good for use in distance learning (e-learning). Google Classroom is a Google product that connects to Gmail, drive, hangout, YouTube, and the deep calendar. The many facilities provided by google classroom will make it easier for teachers to carry out learning activities (Sukmawati \& Nensia, 2019). There are four benefits of the Google Classroom application, first, Google Classroom has the potential to minimize or shorten communication and workflows for students by providing an access point to a series of discussions and assignments; second, the Google Classroom application can help students to keep their documents more organized, because all work or assignments can be saved easily with no paper required. ; third, educators can more quickly identify learners who may have difficulty with their tasks; fourth, the assessment process can be simplified because of the features associated with the delivery of assessment of students (Dewi et al., 2020; Setiawan \& Wicaksono, 2020; Sukmawati \& Nensia, 2019). The google classroom application facilitates the learning process because teachers and students can collect assignments, distribute assignments, and assess assignments without being bound by lesson time limits.

The procedure for using the Google Classroom application is also very easy to understand and operate. Educators can create and organize classrooms in a matter of minutes, and then instantly create content for students. Educators only need to design a class consisting of students according to the real class or real class in school by using their respective emails. Thus, using the google classroom application in learning can save time, keep classes organized, and improve communication with students (Dewi et al., 2020; Setiawan \& Wicaksono, 2020). Also, the class design that applies to Google Classroom is environmentally-friendly. This is because students do not need to use paper when submitting assignments (Sukmawati \& Nensia, 2019).

Thus, carrying out the regulations that the government has made to stay at home during the Covid-19 pandemic, educational institutions are making innovations, namely online learning. Online learning can run using a variety of applications available on the Play Store or the App Store as a learning media. One that is widely used by educators is the Google Classroom application. Through google classroom, it is hoped that the distance learning process can be more effective and efficient without reducing the quality of learning during the Covid-19 pandemic.

Several studies on learning using the google classroom application were conducted by (Bhimani, 2020) which stated that google classrooms are a good platform for teaching physiology and improving learning even though in virtual form. Then the research conducted by (Dewi et al., 2020) stated that google classroom can improve students' scores in reading comprehension. Another study was also conducted by (Pramono et al., 2019) which stated that the use of N-gram in improving the optimization of sentiment results in google classroom can increase accuracy by 6.7 and AUC by $4 \%$ compared to not using $\mathrm{N}$-gram. The purpose of this study is to describe the implementation of based e-learning-ICT learning using the Google Classroom application during the Covid-19 pandemic in public high schools.

\section{Methods}

The research method uses descriptive qualitative, which is a writing that describes the actual situation about an object understudy, following the actual situation at the time of the study. The research sample was students of SMA Negeri 1 Tambangan class X MIA.1. Research data were collected through observation, interviews, and documentation study. Observations are made to monitor the implementation of learning using the google classroom application. Then interviews were conducted with 5 students using 
an interview guide. Furthermore, the documentation study is to see students' understanding of the subject matter given by the teacher based on the assignments that have been done by students.

Data analysis in this study used data analysis techniques Miles and Huberman models, namely data reduction, data presentation, and concluding. All the data obtained were collected, selected, simplified, then summarized by classifying and selecting the required data and organizing the data to make it more systematic. Finally, a meaningful conclusion is drawn.

\section{Result and Discussion}

Based on the results of observations and interviews with high school students of class X MIA.1 Tambangan, it is known that the google classroom application is great to be used as a learning medium during the Covid-19 pandemic. This application provides a variety of good features for the implementation of learning effectively and efficiently. Even though learning is carried out from home without meeting face to face, the teaching and learning process can be carried out well. The use of the google classroom application can be through multi-platforms which can be a computer or a cellphone (Sukmawati \& Nensia, 2019). ICT learning using google classroom can work well.

ICT is defined as the study of the design, development, implementation, and management of computer-based information systems, especially software and hardware applications. Information technology according to this definition is related to the use of computers electronically and computer software to change, store, protect, process, transmit, and retrieve all information safely (Hamid, 2016; Kristinawati et al., 2018; Yaumi, 2012). ICT makes a positive contribution to learning in schools and to be effective it requires conscious efforts to mutually cooperate between principals, teachers, parents, students, and all supporting components including adequate infrastructure and infrastructure. ICT in education is as a learning resource, learning aids, learning facilities, competency standards, administrative systems (Hamid, 2016). Learning ICT by e-learning can be optimal if it is supported by learning media.

The procedure for using the google classroom application is very easy to understand and operate. The implementation of ICT learning in class X MIA.1 is scheduled for Monday. Previously, students had created their email addresses to use in the google classroom application. The following are the steps taken in implementing ICT learning using the google classroom application as the media. First, teachers and students download the google classroom application on their cell phones or laptops. The cellphone and laptop must be connected to an internet network, to download via the Playstore/Appstore. Second, teachers and students enter/log into the application using personal email. Third, the teacher makes a classroom entitled "MIA.1 ICT Guidance Classroom" then gives the class code to students. Fourth, students join the class provided by the teacher and are active in the application when the ICT learning is scheduled. Fifth, before giving the subject matter, the teacher took attendance at the students by making an absent post, then the students commented on the comment's column provided. Sixth, the teacher distributes the lesson material, then holds the discussion in the comment's column. Seventh, the teacher makes assignments for the students to do, then the students send the assignments to the teacher's google classroom account.

Based on interviews conducted with six students regarding the implementation of learning using the google classroom application, it can be concluded that: (1) ICT learning using the google classroom application is entertaining because it can be carried out anywhere and anytime; (2) how to apply google classroom is effortless to understand; (3) no paper required to do the task. On the other hand, apart from the many benefits and advantages of the Google Classroom application, there are still several obstacles experienced by X MIA.1 student in learning ICT using the application, namely: (1) economic problems. There are still some students who do not have smartphones or laptops, so it is challenging to learn using the internet network; (2) there are some areas where students live, are not covered by the internet. That way the learning process becomes a little constrained in its implementation. However, students can still overcome these obstacles by borrowing a parent's smartphone or a family member and going to a place that has an internet network. The google classroom application can make students and teachers interact due to personal comments so that students can communicate with the teacher about anything related to the topic discussed. There is also room for interaction between students and students.

The google classroom application is good for use in distance learning (e-learning). Google Classroom is a google product that connects with Gmail, drive, hangout, YouTube, and the deep calendar. The many facilities provided by google classroom will make it easier for teachers to carry out learning activities (Sukmawati \& Nensia, 2019). The teacher can upload the material to be discussed. Before starting the meeting, students can view and download the material directly on the google classroom application. There are four benefits of the Google Classroom application, first, Google Classroom has the potential to minimize or shorten communication and workflows for students by providing an access point 
to a series of discussions and assignments; second, the Google Classroom application can help students to keep their documents more organized, because all work or assignments can be saved with no paper required; third, educators can more quickly identify learners who may have difficulty with their tasks; fourth, the assessment process can be simplified because of the features associated with the delivery of assessment of students (Dewi et al., 2020; Setiawan \& Wicaksono, 2020; Sukmawati \& Nensia, 2019). The google classroom application facilitates the learning process because teachers and students can collect assignments, distribute assignments, and assess assignments without being bound by lesson time limits (Anshari et al.,2017).

Data collected over a period of time to define the functioning of Google Classroom and provides an overview in terms of teacher and student perspectives (Iftakhar, 2016). Some ideas are examined on the basis of these observations and it has been concluded that adaptation of recent and future technology such as virtual classrooms is a must to ensure quality education.

The use of the Google Classroom application can also improve students' cognitive skills. The results of this study are in line with research conducted by (Bhimani, 2020) which states that the google classroom is a good platform for teaching physiology and improving learning even though it is in virtual form. Then the research conducted by (Dewi et al., 2020) stated that google classroom can improve students' scores in reading comprehension. Another research was also conducted by (Sukmawati \& Nensia, 2019) which stated that google classrooms play a role in learning English, it is proven that students can focus on their discipline because the assignment given has a deadline.

The results of this study are in line with research conducted by (Al-Maroof \& Al-Emran, 2018) which states that the use of the google classroom application has a positive impact on student learning achievement. Another study was also conducted by (Pramono et al., 2019) which stated that the use of Ngram in improving the optimization of sentiment results in google classroom can increase the accuracy by 6.7 and AUC by $4 \%$ compared to not using N-gram.

\section{Conclusion}

Google Classroom is one of the most effective and easiest ways to study online for both in-class and remote learning. It's free, incorporates the Google ecosystem of tools including Docs and Slides for easy distribution of information, and provides easy assessment of student work. In developing each student's skills and abilities, Google Classroom is very beneficial. By themselves and through encouragement, students will understand. Through Google Class, students will discover new material by asking them to actively learn. Although the role of the teacher is very essential for learning the information taught, the supervisor's expertise can easily be obtained by the students. Technological infrastructure must, however, promote the use of the Google Classroom platform in learning. In order for Google Classroom to work well, it requires a set of computers and the internet. Google Class provides the teacher facilities to upload materials. In essential for learners to access the material without any spatialtime restrictions, teachers must organize the material and upload it to Google Class, in the form of text or articles, audio, photos, videos, and many other teaching materials. Moreover, the submission of online assignments by students can also be supervised in an organized way. The google classroom application is great to use for distance learning ICT during the Covid-19 pandemic. There are several advantages of the google classroom application, including flexibility in terms of time and place, easy to understand and operate, an effective and efficient use, and a more accurate learning evaluation process.

\section{References}

Al-Maroof, RAS, \& Al-Emran, M. (2018). Students acceptance of google classroom: An exploratory study using PLS-SEM approach. International Journal of Emerging Technologies in Learning, 13(6), 112123. https://doi.org/10.3991/ijet.v13i06.8275

Alqudah, NM, Jammal, HM, Saleh, O., Khader, Y., Obeidat, N., \& Alqudah, J. (2020). Perception and experience of academic Jordanian ophthalmologists with E-Learning for undergraduate course during the COVID-19 pandemic. Annals of Medicine and Surgery, 59(June), 44-47. https://doi.org/10.1016/j.amsu.2020.09.014

Anderson, J. (2005). IT, e-learning and teacher development. International Education Journal, 5(5), 1-14.

Anshari, M., Almunawar, M. N., Shahrill, M., Wicaksono, D. K., \& Huda, M. (2017). Smartphones usage in the classrooms: Learning aid or interference?. Education and Information Technologies, 22(6), 3063 3079

Baiyere, A., \& Li, H. (2016) 'Application of a virtual collaborative environment in a teaching case'. In AMCIS 2016: Surfing the IT Innovation Wave - 22nd Americas Conference on Information Systems

Bhimani, NT (2020). Google Classroom platform for Physiology teaching in Medical College. 3, 295-303. 
Dewi, N., Zahrovi, E., \& Sulistyawati, MES (2020). The Implementation Of Google Classroom In Improving Students 'Reading Comprehension At Man 4 Jakarta. Lingual: Journal of Language and Culture, 9(1), 21. https://doi.org/10.24843/lilc.2020.v09.i01.p04

Hakim, A.B., (2016). Efektifitas Penggunaan E-Learning Moodle, Google Classroom Dan Edmodo. ISTATEMENT: Information System and Technology Management, 2(1).

Hamid, MA (2016). Development of ICT-Based Student Learning Outcomes Assessment Instruments in Basic Electrical Electronics Learning. VOLT: Scientific Journal of Electrical Engineering Education, 1, 37-46. https://doi.org/http://dx.doi.org/10.30870/volt.v1i1.822

Hardjana, Agus M. (2003). Komunikasi Intrapersonal dan Interpersonal, Yogyakarta : Kanisius

Iftakhar, Shampa. "Google classroom: what works and how?." Journal of Education and Social Sciences 3 (2016): 12-18.

Izenstark, A., \& Leahy, K. L. (2015). Google classroom for librarians: features and opportunities. Library Hi Tech News, 32(9), 1-3.

Jaya Komar C. Koran. Aplikasi e Learning dalam pengajaran dan pembelajaran di sekolah-sekolah Malaysia: Cadangan pelaksanaan pada senario masa kini, pasukan projek rintis sekolah bestari bahagian teknologi pendidikan, Kementerian pendidikan malaysia

Kristinawati, E., Susilo, H., \& Gofur, A. (2018). ICT Based-Problem Based Learning on Students' Cognitive

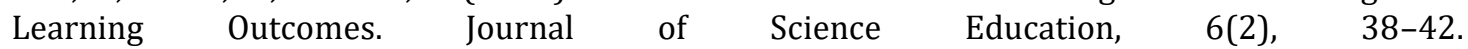
https://doi.org/http://dx.doi.org/10.17977/jps.v6i2.11683

Martínez-Monés, A., Reffay, C., Torío, J. H., \& Cristóbal, J. A. M. (2017, October). Learning Analytics with Google

Classroom: Exploring the possibilities. In Proceedings of the 5th International Conference on Technological

Ecosystems for Enhancing Multiculturality (p. 47). ACM

Liu, H. C., \& Chuang, H. H. (2016). Integrating Google Classroom to Teach Writing in Taiwan. Minnesota eLearning Summit.

Mayer, RE (2019). Searching for the role of emotions in e-learning. Learning and Instruction, May, 101213. https://doi.org/10.1016/j.learninstruc.2019.05.010

Miarso, Y., (2004). Menyemai benih teknologi pendidikan, Kencana. Smaldino, S.E., Lowther, D.L. \& Russell, J.D., (2008). Instructional technology and media for learning.

Pramono, F., Didi Rosiyadi, \& Windu Gata. (2019). Integration of N-gram, Information Gain, Particle Swarm Optimization on Naïve Bayes for Optimization of Google Classroom Sentiment. Journal of RESTI (Systems Engineering and Information Technology), 3(3), 383-388. https://doi.org/10.29207/resti.v3i3.1119

Remuzzi, A., \& Remuzzi, G. (2020). COVID-19 and Italy: What next? Lancet, 395, 1225-1228. 10.1016/S0140-6736(20)30627-9.

Romi Satria Wahono. Meluruskan Salah Kaprah Tentang E-Learning. http://romisatriawahono.net/2008/01/23/meluruskan-salahkaprah-tentang-e-learning/. diakses tanggal 24 Juli 2014

Roni Hamdani, A., \& Priatna, A. (2020). The Effectiveness of the Implementation of Online Learning (Full Online) during the Covid-19 Pandemic at the Elementary School Level in Subang Regency. Didactic: Scientific Journal of PGSD STKIP Subang, 6(1), 1-9. https://doi.org/10.36989/didaktik.v6i1.120

Sadikin, A., \& Hamidah, A. (2020). Online Learning Amid the Covid-19 Outbreak. Biodics, 6(2), 109-119. https://doi.org/10.22437/bio.v6i2.9759

Setiawan, D., \& Wicaksono, SL (2020). Google Classroom Usability Evaluation Using System Usability Scale. $\begin{array}{lllll}\text { Walisongo Journal of Information } & \text { Technology, } & 2(1),\end{array}$ https://doi.org/10.21580/wjit.2020.2.1.5792

Sukmawati, S., \& Nensia, N. (2019). The Role of Google Classroom in ELT. International Journal for Educational and Vocational Studies, 1(2), 142-145. https://doi.org/10.29103/ijevs.v1i2.1526

Waksena. E- Learning Ilmu Pendidikan. http://elearningpendidikan.com/e-learning-ilmupendidikan.html. diakses tanggal 22 Juli 2014

Wijaya, A. (2016, February). Analysis of Factors Affecting the Use of Google Classroom to Support Lectures. In The 5th International Conference on Information Technology and Engineering Application (ICIBA2016). Bina Darma University.

Yaumi, M. (2012). Development of English Teaching Materials for Specific Purpose Based on Tick. Lentera Pendidikan: Journal of Tarbiyah and Teacher Training, 15(2), 144-160. https://doi.org/10.24252/lp.2012v15n2a2 